\title{
Model Pengembangan Pendidikan Karakter di Pesantren Khalaf (Studi Kasus di Pondok Pesantren Modern Muhammadiyah Boarding School Yogyakarta)
}

\author{
Yumidiana Tya Nugraheni \\ UIN Sunan Kalijaga, Yogyakarta, Indonesia \\ yumidianatya@gmail.com \\ Agus Firmansyah \\ UIN Sunan Kalijaga, Yogyakarta, Indonesia \\ agusfirmansyahbinjawari@gmail.com
}

\begin{abstract}
Humans begin to lose their true character identity. Humans have abandoned the values of religiosity and spirituality. The character that is built is the character of pragmatism, hedonism, and materialism. This research is a field research and the method of collecting data is observation to observe the character education development model, interviews by asking questions to the asatidz, administrators and students about the character education development model, and the problems faced during implementation and documentation. This research aims to determine the character values instilled in students in the Yogyakarta Muhammadiyah Boarding School and determine the model of character education development in Yogyakarta Muhammadiyah Boarding School. The results of this research are the formation of characters in Yogyakarta Muhammadiyah Boarding School consists of several values. These values include: respect, responsibility, honesty, tolerance, discipline, help, caring for others and cooperation, courage, and democracy. The pillars of character education include: pesantren residents, kitab kuning, santri organizations and pesantren culture. Based on the four pillars of character education and democratic kyai leadership and the formation of pesantren culture, it produces a holistic-inclusive character education model in Yogyakarta Muhammadiyah Boarding School.
\end{abstract}

Keywords: Development; Character building; Khalaf boarding school 


\begin{abstract}
Abstrak
Penelitian ini bertujuan mengetahui nilai-nilai karakter yang ditanamkan kepada santri di PPM MBS Yogyakarta dan mengetahui model pengembangan pendidikan karakter di PPM MBS Yogyakarta. Penelitian ini merupakan penelitian kualitatif. Jenis penelitian ini adalah studi kasus dan metode dalam mengumpulkan data-data tersebut yakni observasi untuk mengamati model pengembangan pendidikan karakter, wawancara dengan mengajukan beberapa pertanyaan kepada asatidz, pengurus dan santri tentang model pengembangan pendidikan karakter, serta kendala yang dihadapi pada saat pelaksanaannya dan dokumentasi. Hasil penelitian ini adalah pembentukan karakter di PPM MBS Yogyakarta terdiri dari beberapa nilai. Nilai-nilai tersebut antara lain: rasa hormat, tanggung jawab, kejujuran, toleransi, disiplin, tolong-menolong, peduli sesama dan kerjasama, keberanian, dan demokratis. Pilar-pilar pendidikan karakter tersebut antara lain: warga pesantren, kitab kuning, organisasi santri dan budaya pesantren. Berdasarkan empat pilar pendidikan karakter yang dimiliki PPM MBS Yogyakarta dan peran kyai yang bersifat demokratis selama kepemimpinan dan pembentukan budaya pesantren, menghasilkan model pendidikan karakter holistik-inklusif di PPM MBS Yogyakarta. Model pendidikan karakter holistic-inklusif merupakan salah satu alternatif pengembangan pendidikan karakter yang dapat digunakan dari internalisasi pendidikan karakter kepada peserta didik.
\end{abstract}

Kata kunci: Boarding School; Pendidikan Karakter; Pesantren Khalaf

\title{
A. Pendahuluan
}

Pendidikan merupakan usaha sadar manusia untuk membentuk manusia yang mampu memiliki keselarasan antara ranah kognitif, afektif, dan psikomotorik. Keselarasan tiga komponen tersebut dalam terminologi agama islam disebut dengan istilah insan kamil. Insan kamil adalah manusia yang senantiasa menjalin hubungan baik dengan Tuhan, manusia, dan alam. Relasi manusia dengan tuhan tercermin pada nilainilai religiositas dan spiritualitas beragama. Religiusitas dalam agama Islam merupakan atribut yang identik dengan iman dan Islam. Spiritualitas dalam Islam identik dengan ihsan. Religiusitas mencakup kata alim atau ulama. Spiritualitas mencakup kata arif.

Disamping membangun hubungan dengan tuhan, manusia diharuskan mampu membangun hubungan dengan sesame manusia. Hubungan manusia dengan manusia merupakan hubungan yang didasarkan pada nilai-nilai keadilan, keterbukaan, toleransi, dan kebersamaan. Manusia selalu membutuhkan manusia lain. Manusia dibentuk dan ditolong dengan manusia lain. Keberadaan manusia yang selalu berinteraksi dengan manusia lain dikenal dengan makhluk sosial. Hubungan manusia dengan alam merupakan hubungan yang bersifat melestarikan dan menjaga siklus alam. Manusia 
senantiasa memposisikan alam sebagai mitra bersama dalam kehidupan. Mitra bersama dalam kehidupan adalah manusia mempunyai peran sebagai sutradara dan actor dalam menjaga kelestarian lingkungan.

Permasalahan hubungan manusia dengan tuhan yang terjadi di dunia muslim antara lain fanatisme faham, eksklusivitas faham keagamaan, dan ajaran takfiri. Ketiga hal tersebut merupakan dampak negative penguatan ideology keagamaan. Yang diajarkan secara parsial. Salah satu contoh dari tersebut adalah pembubaran organisasi hizbu at-tahrir yang membahayakan NKRI dengan faham khilafah yang diajarkan secara fanatic dan eksklusif. Berdasarkan realitas yang terjadi di dunia kontemporer hubungan relasi manusia dengan tuhan hanya mencakup permasalahan simbolik. Penyembahan manusia terhadap tuhan hanya sebatas ragawi. Manusia gersang akan spiritualitas. Kegersangan spiritualitas inilah yang menjadikan manusia mudah menyalahkan orang lain dan menganggap golongannya yang paling baik yang berhak masuk surga.

Relasi manusia dengan manusia lain didasarkan cara berpikir pragmatisme dan hedonisme. Manusia memandang manusia lain sebagai objek yang dimanfaatkan dan dibutuhkan sesuai kesenangan dirinya. Manusia tidak memiliki nilai-nilai ideal dalam bermasyarakat. Setiap hubungan yang terjalin antara manusia dalam rangka mencapai manfaat dan kesenangan semata. Hubungan seperti ini berakibat dekadensi moral dan krisis identitas. Dekadensi moral dan krisis identitas tersebut telah terjadi di Indonesia. Beberapa kasus permasalahan dekadensi moral dan kritis identitas antara lain: pertama, seorang guru yang dikeroyok lima siswa ketika proses pembelajaran di SMK NU 3 Kaliwungu.(Hidayat, 2020) Kedua, siswa yang mengamcam gurunya karena tidak mau diingatkan dari kesalahannya yaitu merokok di kelas. Peristiwa tersebut terjadi di SMP Swasta di Gresik.(Purnomo, 2020) Ketiga, Sekelompok anak SMA yang tidak merasa bersalah terhadap perilaku menyimpang yang dilakukan. Perilaku menyimpang tersebut adalah perundungan terhadap siswi SMP. Peristiwa tersebut terjadi di kalimantan barat.(Lubis, 2019)

Relasi manusia dengan alam semesta cenderung eksploitasi. Manusia memanfaatkan sesuai dengan untung-rugi. Alam merupakan objek yang senantiasa diperas dan diambil manfaatnya untuk kepentingan materialis pemilik perusahaan atau manusia secara personal. Dampak dari eksploitasi tersebut siklus alam tidak seimbang akhirnya mengakibatkan bencana alam.

Berdasarkan tiga permasalahan tersebut manusia mulai kehilangan jati diri yang nampak yaitu akhlak/ karakter. Manusia telah meninggalkan nilai-nilai religiusitas dan spiritualitas. Karakter yang dibangun karakter pragmatism, hedonisme, dan 
materialisme berlebihan. Manusia selalu menuruti keinginan daripada kebutuhan. Hal tersebut dikarenakan disorientasi dalam memenuhi kebutuhan.

Ketika manusia berbicara keinginan maka hakikatnya karakter manusia tersebut sudah kategori kurang baik. Sebaliknya manusia berbicara kebutuhan maka hakikatnya karakter manusia tersebut baik. Hal ini tersebut diperkuat dengan pembelajaran akhlak/ karakter di sekolah maupun keluarga dominan dengan moral knowing. Moral knowing adalah pembelajaran akhlak atau karakter yang memfokuskan pada pengetahuan materi karakter. Anak diberikan materi tentang pengertian karakter, contoh karakter, manfaat karakter. Hal ini berdampak evaluasi pembelajaran karakter hanya terfokus pada ranah kognitif.

Pesantren merupakan lembaga pendidikan Islam dengan pondok, masjid, santri, pengajaran kitab kuning dan kiai sebagai elemen dasarnya.(Dhofier, 1984, p. 44) Kiai adalah seorang yang mumpuni dalam agama Islam yang merupakan pendiri pondok dan melakukan pengajaran agama kepada para santri. Santri adalah seorang yang belajar pada kiai di pesantren. Pondok atau asrama adalah tempat tinggal santri selama menempuh pendidikan di pesantren. Masjid berkedudukan sebagai sentral kegiatan dan pendidikan. Kitab kuning sebagai sumber belajar dengan topik pengajaran nahwu sharaf, fiqh, ushul fiqh, hadits, tafsir, tauhid, tasawuf dan etika, dan cabang lainnya seperti tarikh dan balaghah. Pesantren merupakan lembaga pendidikan Islam khas Indonesia.

Pesantren yang merupakan lembaga pendidikan Islam yang Khas Indonesia telah berkembang pesat. Perkembangan pesantren tersebut memiliki variasi corak dan keunikan masing-masing. Keunikan dan corak pesantren secara garis besar dibagi menjadi tiga. Pengelompokan pesantren dijelaskan lebih rinci oleh Ridlwan Nasir, yaitu pesantren dibagi menjadi lima kelompok yang berbeda. Pertama pondok pesantren salaf atau klasik, yaitu pondok pesantren yang memiliki sistem pendidikan salaf (weton dan srogan) dan sistem klasikal (madrasah) salaf. Kedua pondok pesantren semi berkembang, yaitu pondok pesantren yang di dalamnya terdapat sistem pendidikan salaf dan sistem klasikal swasta dengan kurikulum 90\% agama dan 10\% umum. Ketiga pondok pesantren berkembang yang hampir sama dengan pondok pesantren semi berkembang, namun dalam kurikulumnya lebih variatif, yakni $70 \%$ agama dan $30 \%$ umum. Keempat pondok pesantren khalaf atau modern, yaitu pondok yang lebih lengkap lembaga pendidikannya, antara lain diselenggarakannya sistem sekolah umum dengan penambahan diniyah (praktek membaca kitab kuning), perguruan tinggi, bentuk koperasi dan dilengkapi dengan takhasus. Kelima pondok pesantren ideal yaitu pondok pesantren yang memiliki lembaga pendidikan yang lebih lengkap, terutama bidang 
keterampilan dengan tidak meninggalkan ciri kepesantrenan yang masih relevan dengan kebutuhan masyarakat dan perkembangan zaman.(Nasir, 2005, pp. 87-88).

Pondok Pesantren Modern Muhammadiyah Boarding School Prambanan Yogyakarta (PPM MBS Prambanan) adalah Pendidikan formal (SMP dan SMA) yang berbasis asrama (boarding). Model pendidikan sistem boarding school merupakan terobosan dalam bidang pendidikan yang mengadaptasi sistem pesantren dan sekolah formal. Sistem pendidikan tersebut mendapat sambutan dan menarik minat masyarakat perkotaan modern pada tahun 2010 sampai sekarang. Banyaknya masyarakat kepercayaan masyarakat terhadap sistem tersebut mengakibatkan perkembangan lembaga pendidikan berbasis boarding banyak berdiri di Indonesia. Salah satu lembaga pendidikan boarding yang mengalami perkembangan pesat adalah Muhammadiyah Boarding School (MBS) Prambanan Yogyakarta.(Yogyakarta, 2020b, p. 35).

PP MBS Yogyakarta merupakan sekolah yang diminati oleh masyarakat. Masyarakat yang memasukkan anak-anaknya di PP MBS Yogyakarata disebabkan oleh beberapa hal. Salah satu sebab yang dominan adalah integrated kurikulum (kurikulum terpadu) yang diterapkan. Kurikulum tersebut menyeimbangkan dan memadukan kurikulum SMP dan SMA dari Diknas, kurikulum pesantren modern dan kurikulum kema'ahadan. Kurikulum kema'hadan yang berisikan qira'atul kutub, tahfidz alQur'an dan al-Hadits, al-lughah al-yaumiyah, olahraga, beladiri, kepanduan, dan lain sebagainya.(Yogyakarta, 2020b, p. 28).

Pondok pesantren MBS Yogyakarta yang berdiri pada tahun 2008 sampai sekarang. Pondok pesantren tersebut mengalami perkembangan yang signifikan. Perkembangan yang signifikan dapat ditinjau dari dua aspek utama. Pertama, jumlah santri MBS yang banyak. Kedua lulusan/output yang dapat diterima di perguruan tinggi luar dan dalam negeri serta mampu menjadi agen perubahan dalam masyarakat.

Penelitian dengan tema pesantren dan pendidikan karakter telah banyak dilakukan antara lain: pertama, penelitian Abdurrahman menjelaskan tentang implementasi manajemen kurikulum pesantren didasarkan pada karakter universal menunjukkan keefektifan yang lebih baik dibandingkan sekolah formal. Keefektifan tersebut dipengaruhi dua faktor antara lain: intensitas santri dan kyai, dan role model dari kyai.(Abdurrahman, 2017) Kedua, penelitian Muhammad Misbah menjelaskan tentang Pola relasi antara santri dan kyai di pesantren tersebut adalah patronase plus. Relasi tersebut diperkuat dengan internalisasi nilai-nilai religius yang didasarkan pada kitab kuning. Nilai-nilai tersebut dirangkai dengan beberapa metode antara lain: keteladalan (uswatun hasanah), pembiasaan, praktek langsung, dan pujian dan sanksi.(Misbah, 2019) 
Ketiga, penelitian Ahmad Nur Fatih menjelaskan tentang penanaman nilai-nilai mandiri dan disiplin menggunakan beberapa pendekatan yaitu pendekatan among, pendekatan kekeluargaan, pendekatan keterampilan proses, pendekatan pembiasaan, pendekatan emosional, pendekatan rasional, serta pendekatan fungsional. Disamping terdapat beberapa pendekatan, pondok tersebut menggunakan beberapa metode antara lain: metode teladan, metode ceramah, metode qishah, metode pembiasaan, metode hiwar, dan metode pemberian sanksi. (Ahmad, 2018)

Keempat, penelitian Tindrawati Nasiki menjelaskan tentang Model Implementasi pendidkan karakter berbasis kemandirian-kultural. Pendidikan karakter berbasis kemandirian. Hal tersebut ditinjau dari tiga faktor yaitu pengetahuan yang hidup (living knowledge), Pesantren mengiternalisasikan nilai-nilai kewirausahaan dan kemandirian sehingga santri dapat mengisi lapangan pekerjaan dan membuat lapangan pekerjaan, dan perilaku pendidik yang sederhana dan bersahaja.(Nasiki, 2017) Kelima, penelitian Imam Syafe'i menjelaskan pesantren merupakan lembaga pendidikan yang berbasis edukatif dan transformatif nilai-nilai kebaikan.(Syafe'i, 2017)

Disamping kelima penelitian tersebut, adapun artikel-artikel yang berkaitan tentang pendidikan karakter antara lain: artikel Nurzula Yenti Basyaruddin dan Rifma menjelaskan penanaman pendidikan karakter dalam proses pembelajaran di sekolah.(Basyaruddin \& Rifma, 2020), artikel Saihu menjelaskan tentang pendidikan yang mengunakan proses etno pedagogy mampu membentuk manusia menjadi humanis, toleran, dan inklusif.(Saihu, 2019), Artikel Hafidh Nur Fauzi dan Waharjani menjelaskan tentang penanaman nilai-nilai pendidikan karakter dapat melalui pembelajaran tahfidzul Qur'an(Fauzi \& Waharjani, 2019). Artikel Rohmat menjelaskan tentang pengelolaan pendidikan karakter yang memadukan nilai religius dan multikultural berdampak efektif dan signifikan bagi peserta didik di Madrasah Ibtidaiyah. (Rohmat, 2019), dan artikel Mukhamad Ilyasin menjelaskan aktualisasi nilai-nilai karakter dimulai dari proses penerimaan siswa, penempatan siswa, dan penataan kelas.(Ilyasin, 2019)

Penelitian dan artikel tersebut menfokuskan pada pendidikan karakter pesantren salaf dan pendidikan karakter di sekolah. Peran Kyai dalam pembentukan karakter merupakan sesuatu yang dominan. Model pengembangan karakter yang dikembangkan dengan basis cultural-kemandirian. Sementara penelitian model pengembangan pendidikan karakter yang dilakukan di persantren khalaf berbeda dengan pesantren salaf. Pola kepemimpinan yang bersifat demokratis akan berdampak pada model pengembangan karakter oleh sebab itu penelitian ini bertujuan mengetahui nilai-nilai karakter yang ditanamkan kepada di PPM MBS yogyakarta dan mengetahui model pengembangan pendidikan karakter PPM MBS Yogyakarta. 


\section{B. Pembahasan}

\section{Konsep Pendidikan Karakter di Era Postmodernisme}

Pendidikan karakter merupakan bagian terpenting dari pendidikan nasional. Menurut Lickona, pendidikan karakter tersusus dari tiga bagian utama yaitu karakter mulia (good character) meliputi pengetahuan tentang kebaikan (moral knowing) lalu menimbulkan komitmen atau niat terhadap kebaikan (moral feeling), dan akhirnya benar-benar melakukan kebaikan (moral behavior).(Lichona, 2013, p. 51). Karakter berhubungan dengan kepribadian (personality). Manusia berkarakter adalah manusia yang mampu menyesuaikan perilakunya dengan kaidah moral masyarakat yang universal. Pembentukan manusia yang berkarakter dilakukan dengan pengulangan perilaku baik secara berulang-ulang secara disengaja atau tidak disengaja. Dari unsur pengulangan tersebut makan terbentuknya kebiasan yang dilakukan tersebut menjadikan sebuah reflek yang tidak disadari oleh seseorang. Maka dari itu, jika ditinjau dari struktur antropologi kodrati, karakter merupakan sesuatu yang dapat dirubah.

Karakter dapat dibedakan menjadi dua kriteria yaitu: karakter yang dapat diamati (character as seen) dan karakter yang dialami atau berupa pengalaman tentang kehidupan (character as experienced).(Naim, 2012, p. 53) Kecenderungan pemahaman masyarakat umum karakter ditunjukkan dengan keseluruhan sikap yang terus menerus dilakukan secara konsisten, berupa tingkah laku, kebiasaan, pembawaan, dan lainlainnya ini yang sering di lihat sebagai kenyataan. Oleh dari itu, seringkali karakter ini disebut sebagai karakter kasatmata yang yang dapat di lihat dari fenomena indrawi. Sedangkan, hasil dari reaksi seseorang yang bertindak sebagai pelaku dan pelaksana atas dunia diluar dirinya, inilah yang dimaksud karakter yang dialami.

Berdasarkan fenomena yang ada pemahaman seseorang tentang karakter hanya sebatas apa yang dilihat saja, sehingga beberapa orang masih salah dalam menafsirkan maknanya. Maka dalam proses pendidikan, seorang pendidik harus bisa memahamkan peserta didik tentang makna karakter secara menyeluruh baik kasatmata maupun secara alamiah. Sehingga tidak adanya kesalahpahaman dalam memaknai karakter.

Pendidikan karakter identik dengan penanaman nilai-nilai universal. Nilai-nilai universal merupakan proses refleksi secara mendapat terhadap beberapa konseo antara lain: benar-salah, baik-buruk, dan eksplisit-implisit. Refleksi beberapa konsep tersebut mengakibatkan variasi nilai-nilai pendidikan karakter yang dikembangkan negara, organisasi maupun perseorangan.

Nilai-nilai yang dikembangkan dalam pendidikan karakter di negara Indonesia ini berasal dari empat sumber. Pertama, Agama adalah sistem kepercayaan yang terdiri 
dari ritual, simbol, nilai-nilai. Nilai-nilai dalam agama tersebutlah yang menjadi pedoman. Kedua, Pancasila merupakan dasar Negara Kesatuan Republik Indonesia atas prinsip kehidupan kebangsaan dan kenegaraan . Pancasila terdapat dalam pembukaan UUD 1945, maka dari itu keseluruhan nilai-nilai yang ada didalamnya mengatur keseluruhan kehidupan baik di bidang politik, hukum, ekonomi, kemasyarakatan, budaya dan seni. Ketiga, budaya merupakan bagian penting dalam kehidupan bermasyarakat. keberagaman budaya di negara Indonesia banyak, walaupun demikian nilai-nilai budaya yang diakui oleh masyarakat harus didasarkan pada konsep dan arti dalam menjalin komunikasi antar anggota masyarakat agar tidak terjadi permusuhan. Keempat, Tujuan Pendidikan nasional.

Kementrian Pendidikan Nasional di Indonesia bernama Penguatan Pendidikan Karakter (PPK), mengidentifikasi ada 5 nilai utama karakter bangsa yaitu: pertama, Nilai karakter religius mencerminkan keberimanan terhadap Tuhan yang Maha Esa yang diwujudkan dalam perilaku melaksanakan ajaran agama dan kepercayaan yang dianut. Disamping itu pemeluk agama senantiasa membisakan toleransi dan hidup rukun dengan pemeluk agama lain. Penjabaran nilai religius antara lain: cinta damai, toleransi, menghargai perbedaan dan kepercayaan, teguh pendirian, percaya diri, kerja sama antar pemeluk agama dan kepercayaan, anti buli dan kekerasan, persahabatan, ketulusan, tidak memaksakan kehendak, mencintai lingkungan, dan melindungi yang kecil dan tersisih.

Kedua, Nilai karakter nasionalis adalah internaliasai pikiran dan tindakan yang menunjukkan kecintaan terhadap negara kesatuan Indonesia. Adapun bentuk perilaku yang mencerminkan sikap nasionalis antara lain: toleransi terhadap budaya bangsa, melestarikan kemajemukan budaya bangsa, menjaga plutalitas budaya, tradisi, suku, dan agama dan kepedualian terhadap lingkungan dan hukum.

Ketiga, Nilai karakter mandiri pola berpikir dan berperilaku yang berusaha untuk mengejar setiap cita-cita, impian dan harapan. elemen nilai mandiri antara lain gigih, tangguh, ahli dalam bidangnya, kreatif, keberanian, dan menjadi pembelajar selama hidup. Keempat, Nilai karakter gotong royong tercermin dari perilaku kerjasama dalam segala bidang kegiatan. Bagian dari nilai gotong royong adalah bermusyawarah dan berkolaborasi

Kelima, Nilai karakter integritas adalah nilai yang memegang teguh komitmen. Adapun nilai-nilai yang perlu dikembangkan antara lain tanggung jawab sebagai warga negara, aktif terlibat dalam kehidupan sosial, istiqomah dalam kebenaran dan kebaikan. Sub nilai integritas antara lain cinta pada kejjujuran, berperilaku jujur, dan senantiasa mem, buat sistem yang mengrahkan manusia untuk berbuat jujur. 
Nilai-nilai tersebut merupakan satu-kesatuan yang saling membutuhkan dan melengkapi. Nilai-nilai tersebut merupakan pilar-pilar penting yang saling terkait. Nilai-nilai tersebut memiliki fondasi dasar yaitu keimanan dan ketakwaan kepada Tuhan Yang Maha Esa.(Indonesia, 2017) Mengingat dari pentingnya pendidikan karakter diatas, Megawangi memerinci 9 pilar karakter mulia yang penting untuk ditanamkan dalam pendidikan karakter, yaitu: (1) Cinta kepada Allah dan kebenaran; (2) Tanggung jawab, disiplin, dan mandiri; (3) Amanah;(4) Hormat dan santun; (5) Kasih sayang, peduli, kerja sama; (6) Percaya diri, kreatif, dan pantang menyerah; (7) Adil dan berjiwa kepemimpinan; (8) Baik dan rendah hati; dan (9) Toleransi dan cinta damai.(Megawangi, 2004)

Sebagaimana yang diungkapkan oleh Thomas Lickona bahwa memiliki pengetahuan nilai moral itu tidak cukup untuk menjadi mausia berkarakter, nilai moral harus disertai dengan adanya karakter bermoral.(Lichona, 2013, p. 72) Beberapa tahapan-tahapan yang harus diperhatikan dalam proses pembentukan karakter antara lain: pertama, Moral Knowing yaitu Dalam proses pembentukan karakter, maka peserta didik harus memahami dasar pengetahuannya. Ranah pengetahuan ini bersifat kognitif. Penerapan metode ini dengan cara menyampaikan pada anak tentang pengajaran pengertian kebaikan yang berniali atau memberikan pemahaman tentang nilai-nilai kebaikan. Maka dari itu pendidikan karakter harus berdasarkan pengetahuan yang bersifat kognitif terlebih dahulu. Dengan demikian dalam proses pembentukan karakter harus didasarkan dengan pengenalan pengetahuan yang mendalam sampai memiliki pemahaman yang komprehensif agar merespon kebaikan dalam lingkungan sekitarnya serta mampu memahami fenomena yang terjadi disekitar. Setelah itu mampu mengeneralisasikan pemahaman yang sudah ada serta mengevaluasi, sehingga mempunyai pemahaman yang kokoh.

Bagian ini mendasarkan tentang pengetahuan kebenaran dan kebaikan. Beberapa aspek yang termasuk dalam moral knowing, antara lain: kesadaran moral (moral awareness), pengetahuan tentang nilai-nilai moral (knowing moral value), penentuan sudut pandang (perspective taking), logika moral (moral reasoning), keberanian mengambil (decision making), menentukan sikap dan pengenalan diri (self knowledge).(Majid \& Andayani, 2012, p. 31) Keseluruhan aspek tersebut jika telah dipahami peserta didik dengan baik, maka dapat memberikan kontribusi bagi pembentukan karakter seseorang.

Kedua, Moral Loving/ Moral Feeling yaitu dasar pengetahuan kebaikan saja belum menentukan seseorang mampu berkarakter dengan pengetahuannya. Maka perlu adanya aspek perasaan yang ingin berbuat kebaikan guna merealisasikan pengetahuan yang ada. Proses moral loving atau moral feeling tersebut meliputi beberapa hal 
diantaranya: kesadaran akan jati diri (conscience), percaya diri (self esteem), kepekaan terhadap orang lain (emphaty), menyukai kebaikan (loving the good), pengendalian diri (self control), dan kerendahan hati (humility).(Majid \& Andayani, 2012, p. 34) Keseluruhan aspek ini menfokuskan pada wilayah perasaan dan hati nurani.

Ketiga, Moral Doing merupakan hasil dari kedua komponen lainnya. Maka moral doing atau moral action meliputi beberapa aspek yaitu: kompetensi (competence), kehendak (will), dan kebiasaan (habit). Keseluruhan aspek tersebut memberikan kontribusi bagi sisi psikomotor seseorang. Moral doing merupakan indikator keberhasilan dari proses pendidikan karakter, dimana peserta didik senantiasa membiasakan nilai-nilai karakter yang baik dalam kehidupan sehari-hari.(Gunawan, 2012, p. 193).

\section{Meningkatkan Efektivitas Pembelajaran Jarak Jauh (Daring)}

Pendidikan karakter beberapa komponen pendukung. salah satu komponen pendukung adalah nilai-nilai yang dinternalisasikan. Internalisasi nilai-nilai pendidikan karakter yang dikembangkan berbeda-beda berdasarkan lembaga maupun pendapat para ahli. Menurut Megawangi memerinci 9 pilar karakter mulia yang penting untuk ditanamkan dalam pendidikan karakter, yaitu: (1) Cinta kepada Allah dan kebenaran; (2) Tanggung jawab, disiplin, dan mandiri; (3) Amanah;(4) Hormat dan santun; (5) Kasih sayang, peduli, kerja sama; (6) Percaya diri, kreatif, dan pantang menyerah; (7) Adil dan berjiwa kepemimpinan; (8) Baik dan rendah hati; dan (9) Toleransi dan cinta damai.(Megawangi, 2004). Pendapat tersebut diperkuat oleh lembaga living values education (LVE). Lembaga tersebut mengiternalisasikan Menurut living dua belas nilainilai kunci dari kepribadian dan sosial: Perdamaian, Rasa Hormat, Cinta, Kebahagiaan, Kejujuran, Rendah Hati, Tanggung Jawab, Toleransi, Kerja Sama, Kebebasan dan Persatuan.(Suardipa, 2019) Kementrian Pendidikan Nasional di Indonesia bernama Penguatan Pendidikan Karakter (PPK), mengidentifikasi ada 5 nilai utama karakter bangsa yaitu: nilai religious, nasionalis, mandiri, gotong-royong, dan integritas.

Berdsarkan beberapa teori tentang internalisasi pengembangan nilai-nilai tersebut, nilai- nilai tersebut dinterpretasi dan dijabarkan oleh PP MBS menjadi beberapa nilai.Pembentukan karakter di pondok pesantren Muhammadiyah boarding school Yogyakarta terdiri dari beberapa nilai. Nilai-nilai tersebut antara lain: rasa hormat, rtanggung jawab, kejujuran, toleransi, disiplin, Tolong-menolong, peduli sesama dan kerja sama, keberanian, dan demokratis

Pembiasaan perilaku hormat santri dan pendidik dilaksanakan dengan berbagai cara antara lain: 1)Membiasakan santri untuk selalu berpakaian rapi dan bersih, pengontrolan kerapian almari dan tempat tidur. Adanya program ini dimaksudkan untuk 
menanamkan rasa hormat terutama rasa hormat untuk dirinya sendiri. Rasa hormat terhadap diri sendiri ini ditunjukkan dengan menjaga diri sendiri maupun barang-barang pribadi. 2) Piket guru. Pelaksanaan program ini yaitu para guru diharuskan datang ke sekolah paling lambat pikul 06.30 WIB untuk menyambut kedatangan murid di depan gedung kelas. Para guru baris berjajar untuk menyalami murid yang berangkat ke kelas. Tujuan dari program ini adalah memberikan motivasi belajar kepada murid sekaligus mengajarkan kepada murid untuk menghormati guru, yaitu bahwa ridho dari seorang guru adalah salah satu factor penting dalam menuntut ilmu.3) Pembiasaan mengucapkan "Syukron yaa ustadzah" atau "Thank you miss" setiap usai jam pelajaran. Program ini dimaksudkan untuk menanamkan rasa hormat terhadap ilmu dan rasa hormat terhadap pemberi ilmu. 4)Budi daya $5 \mathrm{~S}$ (senyum, salam, sapa, sopan dan santun). Pelaksanaan program ini merujuk pada salah satu perintah Rasulullah. Program ini mengajarkan santri untuk memiliki rasa hormat terhadap seseorang yang lebih tua darinya yaitu minimal dengan mengucapkan salam dan memberi sapaan terlebih dahulu.

Penanaman rasa tanggung jawab dilakukan dengan mengikutkan santri dalam organisasi dan kegiatan pesantren. Hal ini dimaksudkan untuk menanamkan rasa tanggungjawab terhadap Tuhan, diri sendiri, orang lain maupun terhadap lingkungan. Santri ditanamkan untuk memiliki rasa tanggung jawab kepada Allah sebagai hamba yang mengabdi untuk-Nya. Diantara program untuk menanamkan rasa tanggung jawab ini adalah dengan shalat berjamaah lima waktu di masjid, pembiasaan shalat Tahajud dan shalat dhuha serta puasa sunnah senin dan kamis. Sedangkan untuk menanamkan tanggung jawab terhadap diri sendiri, santri diwajibkan untuk merapikan almari dan tempat tidur masing-masing, mencuci dan menyetrika baju sendiri serta dilatih untuk hidup serba mandiri. Untuk melatih rasa tanggung jawa terhadap lingkungan, santri diberi tanggung jawab dalam beberapa piket yang harus dijalankan. Piket tersebut antara lain, piket kebersihan kamar, asrama, kelas serta piket bersih lingkungan. Selain itu juga ada piket membagi lauk untuk santri lainnya. Piket menjadi imam shalat bagi siswa SMA dan piket membaca doa sehabis shalat bagi siswa SMP.

Adapun beberapa organisasi yang ada di Pondok Pesantren Muhammadiyah Boarding School Yogyakarta yaitu: 1) Organisasi IPM (Ikatan Pelajar Muhammadiyah). Organisasi ini merupakan wadah untuk membina santri, yaitu beranggotakan siswi kelas XI SMA. Mereka diberi tugas sebagai penegak disiplin seluruh santriwati baik dalam bidang keamanan, bahasa, kebersihan, kesehatan dan lain sebagainya sehingga bisa dikatakan bahwa IPM adalah jantung kegiatan pondok. Santri diberi tanggungjawab seluruh kegiatan non akademis, mulai dari membangunkan santri, mengatur saf dalam shalat berjamaah, mengontrol kebersihan dan kesehatan, membina bahasa, menyimpan peralatan-peralatan pondok, memberi hukuman ketika ada yang melanggar dal kegiatan 
lainnya. Mereka diberi amanah untuk mengontrol santri mulai dari bangun tidur sampai tidur kembali. 2) Organisasi DK (Dewan Kerabat). Organisasi DK merupakan sebuah organisasi yang dibentuk untuk mengatur menjalankan, dan mengontrol kegiatan kepanduan Hizbul Wathan. Hizbul Wathan merupakan kegiatan ekstra kurikuler wajib di seluruh lembaga pendidikan Muhammadiyah. Anggota dari organisasi ini adalah siswa kelas X dan XI SMA. Dalam organisasi ini siswi dilatih untuk membuat program kerja serta pelaksanaannya dan dilatih untuk mengevaluasi program tersebut. Organisasi ini mengadakan rapat rutin minimal dua minggu sekali guna membahas teknisi pelaksanaan kegiatan sebelum kegiatan dan untuk evaluasi kegiatan setiap usai kegiatan. Para anggota organisasi DK juga diberi tanggungjawab untuk memberikan pelatihan serta menyampaikan materi kepada para anggota pandu dalam kegiatan hizbul wathan. 3) Organisasi perkaderan TS (Tapak suci). Sama seperti halnya organisasi DK, organisasi perkaderan TS merupakan sebuah organisasi yang dibentuk untuk mengatur, menjalankan dan mengontrol kegiatan ekstra kurikuler tapak suci. Anggota dari organisasi ini adalah siswi kelas XI yang telah meraih sabuk biru dalam latihan tapak suci. Anggota dari organisasi perkaderan tapak suci diberi tugas untuk melatih silat seluruh anggota tapak suci. Selain melatih mereka juga diberi tanggung jawab untuk mengontrol dan mengevaluasi kegiatan tapak suci.

Nilai kejujuran tidaklah terlepas dari rasa tanggung jawab, karena kejujuran merupakan buah dari rasa tanggung jawab. Beberapa program yang dilakukan untuk membina kejujuran santri diantaranya adalah dengan memberi amanah pada para bendahara baik bendahara kamar, asrama maupun kelas untuk memegang keuangan dan melaporkannya kepada bendahara pusat. Dengan ini akan dapat dilihat kejujuran santri dalam memegang amanah finansial. Selain itu, untuk menanamkan kejujuran adalah dengan ditegakkan disiplin larangan berbuat curang dalam ujian. Santri yang melanggar disiplin ini akan dikenakan sanksi yang cukup berat. Dengan demikian santri akan dituntut untuk berbuat jujur dalam ujian.

Untuk menumbuhkan rasa toleransi, santri dibiasakan untuk bersosialisasi dengan santri lain yang berbeda latar belakang, ras dan daerah. Program ini didukung dengan pengelompokan kamar santri, yaitu dalam satu kamar beranggotakan anak yang berasal dari berbagai daerah di seluruh penjuru Indonesia dengan berbagai macam sifat dan watak.

Disiplin merupakan kaki dan tangan sebuah lembaga, artinya tanpa disiplin kegiatan yang mengarah pada tujuan tidak akan dapat bergerak secara maksimal. Dalam rangka membentuk disiplin santri, terdapat program-program dan kegiatan rutinitas yang harus ditaati oleh santri sejak bangun tidur sampai tidur kembali. Kegiatan kedisiplinan santri ini didukung dengan adanya jaros atau bel yang memandu sebagian 
besar kegiatan rutinitas santri mulai dari disiplin berangkat ke masjid, disiplin berangkat ke sekolah, sampai disiplin mulainya suatu kegiatan. Untuk menanamkan disiplin dalam mentaati peraturan ini, telah disediakan skala hukuman yang sesuai bagi santri yang melanggar peraturan. Dengan adanya hukuman ini diharapkan dapat membentuk jiwa disiplin dari santri.

Penanaman nilai saling tolong-menolong, peduli sesame dan kerja sama tercipta secara alami di pondok pesantren. Hal ini dikarenakan lingkungan bersosialisasi dan bermasyarakat terjalin sangat kuat. Seluruh santri dihadapkan dengan lingkungan yang bermasyarakat sehingga mereka dituntut untuk hidup dalam atmosfer tolong menolong dan kerja sama. Sebagai contoh, dalam satu kamar diisi oleh kurang lebih 20 orang, dan ketika salah seorang anggota kamar sakit, maka anggota yang lain dituntut untuk merawatnya. Contoh yang lain, ketika salah seorang mendapat masalah tentu akan mendorong yang lainnya untuk membantu atau setidaknya akan muncul rasa kepedulian.

Keberanian merupakan nilai yang perlu ditanamkan kepada santri sebagai seorang calon muballigh di masa depan. Keberanian ini ditanamkan dalam beberapa kegiatan, diantaranya adalah: Latihan pidato, Latihan khotbah Jum'at bagi santri putra. Menjadi MC di berbagai acara, Lomba-lomba seperti lomba pidato, lomba membaca puisi, lomba debat berbahasa dan masih banyak lomba lainnya.

Nilai demokrasi ditanamkan melalui adanya beberapa rapat dan musyawarah kerja. Dalam rapat ini santri diberi kebebasan untuk berpendapat dan menyalurkan ideidenya. Selain diberi kebebasan dalam berpendapat, santri juga diajarkan untuk dapat berlapang dada menerima pendapat orang lain. Di sinilah jiwa demokrasi yang sehat terbentuk.

Berdasarkan data tersebut, Internalisasi nilai-nilai pendidikan karakter yang dikembangkan di MBS Yogyakarta memadukan tahapan antara lain: keteladanan, bimbingan, dorongan atau motivasi, penanaman niat ikhlas, pembiasaan yang keberlanjutan, nasehat, pengulangan, pengorganisasian, dan sentuhan hati nurani. Tahapan tersebut dilaksanakan secara terus-menerus oleh semua warga pesantren.

\section{Model Pengembangan Pendidikan Karakter PPM MBS Yogyakarta}

Pendidikan karakter di topang dengan pilar-pilar yang menguatkan. Salah satu pilar tersebut adalah semua anggota dalam komunitas. Semua anggota dalam komunitas dalam konteks lembaga atau sekolah adalah warga sekolah. Menurut Lickona pendidikan karakter yaitu karakter mulia (good character) meliputi pengetahuan tentang kebaikan (moral knowing) lalu menimbulkan komitmen atau niat terhadap kebaikan 
(moral feeling), dan akhirnya benar-benar melakukan kebaikan (moral behavior) (Lichona, 2013, p. 51). Model pengembangan pendidikan karakter lickona tersebut diperkuat dengan model pengembangan pendidikan karakter dari kementerian pendidikan dan kebudayaan. Kementerian pendidikan dan kebudayaan mengembangkan Model pendidikan karakter yang terintegrasi dengan budaya Indonesia. model pendidikan karakter tersebut merupakan integrasi-interkoneksi dari beberapa bagian yaitu psikologis, sosial-kultural, dan religiositas. Berdasarkan integrasi-interkoneksi tersebut menghasilkan empat pilar utama yaitu : internalisasi nilai ke hati saubari, pengembangan cara berpikir, kesehatan jasmani, dan menjaga rasa kemanusiaan (Walid, 2011).

Berdasarkan dua grand desain tersebut, pendidikan karakter PP MBS Yogyakarta mengiterpretasikan dalam konteks kepesantrenan. Pendidikan karakter di PP MBS Yogyakarta terdiri dari beberapa pilar yang saling mendukung. Pilar-pilar pendidikan karakter tersebut antara lain: warga pesantren, kitab Kuning, Organisasi Santri, budaya pesantren. Warga pesantren yang dimaksud adalah santri, kyai (direktur), ustadz/ustadzah (pendidik), dan karyawan/ karyawati pesantren. Warga sekolah tersebut memiliki kewajiban untuk melaksanakan pesantren. Kewajiban setiap warga sekolah berbeda-beda. Pelaksanaan kewajiban tiap warga pesantren mampu menghasilkan role model. Role model inilah yang menjadi dasar penguat pendidikan karakter di pesantren. Role model inilah dalam teori Lichona masuk pada kategori moral doing atau moral acting.

Kitab kuning merupakan ciri-ciri pesantren. Kitab kuning yang diajarkan di pesantren MBS mengandung nilai-nilai pendidikan karakter. Nilai-nilai pendidikan karakter tersebut tersebar dalam bentuk kitab hadits, sirah nabawiyah dan khulafa arrasyidin. Adapun beberapa contoh hadits yang menjadi sumber nilai-nilai karakter adalah kitab Riyadhus Shalihin, Arbain Nawawi, dan Bulughul Maram. Adapun kitabkitab tarikh yang diajarkan adalah kitab al-Rahiq al-Mahtum dan kitab at-Tarikh alIslamy fii siiroti Rasulillah Sallallahu alaihi wa Sallam. Kitab kuning merupakan pilar pendidikan karakter di PPM MBS Yogyakarta. Pilar kitab kuning tersebut dikategorikan pada moral knowing.

Organisasi santri merupakan bagian dari pembiasaan nilai-nilai pendidikan karakter. Organisasi santri yang terdiri IPM, Tapak suci, Dewan Kerabat merupakan sarana pengembangan dan penerapan nilai-nilai pendidikan karakter. Organisasi santri tersebut masuk dalam kategori moral feeling dan moral acting. Budaya pesantren MBS Yogyakarta merupakan budaya religius yang bersumber pad al-Qur'an dan hadits menurut faham organisasi Muhammadiyah. Budaya pesantren bersifat moderat. Budaya pesantren inilah merupakan pilar yang tidak nampak dalam dokumen PP MBS 
Yogyakarta, namun menjadi hadir di setiap warga pesantren. Peran Kyai (direktur) dalam budaya pesantren bersifat inklusif. Budaya pesantren inklusif yang dimaksud adalah budaya yang diambil dari mengadaptasi dan mengakomodasi pendapat pendidik dan yayasan secara demokratis.

Berdasarkan empat pilar pendidikan karakter yang dimiliki PP MBS Yogyakarta dan peran kyai yang bersifat demokratis salam kepemimpinan dan pembentukan budaya pesantren. Terdapat model pendidikan karakter PP MBS Yogyakarta holistik-inklusif. Holistik adalah semua teori Lickona tentang pendidikan karakter diterapkan di lingkungan pesantren. Inklusif adalah pembiasaan nilai-nilai dan budaya pesantren disepakati dengan proses musyawarah dengan kyai, pendidik, dan persyarikatan dengan mempertimbangkan perkembangan keilmuan yang berkembang.

\section{Simpulan}

Pondok Pesantren Muhammadiyah Boarding School Yogyakarta merupakan sebuah lembaga pendidikan yang berusaha menanamkan nilai- nilai karakter dalam setiap program dan kegiatannya. Dalam lingkup pesantren penanaman tersebut dilakukan secara utuh dalam tiga pusat pendidikan, yaitu di lingkungan asrama, sekolah maupun masyarakat pondok. Seluruh program dan kegiatan baik yang bersifat rutinitas maupun non rutinitas telah disusun secara sistematis sehingga dapat menghasilkan alumni yang tidak hanya mumpuni dalam bidang akademis, namun juga memiliki karakter yang baik di masyarakat. Pembentukan karakter di pondok pesantren Muhammadiyah boarding school Yogyakarta terdiri dari beberapa nilai. Nilai-nilai tersebut antara lain: rasa hormat, tanggung jawab, kejujuran, toleransi, disiplin, Tolongmenolong, peduli sesama dan kerja sama, keberanian, dan demokratis. Pilar-pilar pendidikan karakter tersebut antara lain: warga pesantren, kitab Kuning, Organisasi Santri, budaya pesantren. Berdasarkan empat pilar pendidikan karakter yang dimiliki PP MBS Yogyakarta dan peran kyai yang bersifat demokratis salam kepemimpinan dan pembentukan budaya pesantren. Terdapat model pendidikan karakter PP MBS Yogyakarta holistik-inklusif. Holistik adalah semua teori Lickona tentang pendidikan karakter diterapkan di lingkungan pesantren. Inklusif adalah pembiasaan nilai-nilai dan budaya pesantren disepakati dengan proses musyawarah dengan kyai, pendidik, dan persyarikatan dengan mempertimbangkan perkembangan keilmuan yang berkembang.

\section{DAFTAR PUSTAKA}


Abdurrahman. (2017). Implementasi Manajemen Kurikulum Pesantren Berbasis Pendidikan Karakter. Jurnal At-Turas, IV(2), 279-297.

Ahmad, N. F. (2018). Pendidikan Karakter Mandiri Dandisiplinsantri Pondok Pesantren Mambaus Sholihin Suci Manyar Gresik. Jurnal Ilmu Pendidikan Islam, 16(1), 109-126.

Basyaruddin, N. Y., \& Rifma, R. (2020). Evaluasi Penguatan Pendidikan Karakter. JMKSP (Jurnal Manajemen, Kepemimpinan, Dan Supervisi Pendidikan), 5(1), 4. https://doi.org/10.31851/jmksp.v5i1.3498

Dhofier, Z. (1984). Tradisi Pesantren: Studi tentang pandangan hidup Kiai. LP3ES.

Fauzi, H. N., \& Waharjani. (2019). PENDIDIKAN KARAKTER MELALUI PEMBELAJARAN TAHFIDZ AL-QUR'AN BERBASIS METODE UMMI BAGI SISWA SDIT SALSABILLA SLEMAN. Syamil, 7(2), 131-146.

Gunawan, H. (2012). Pendidikan Karakter Konsep dan Implementasi. Alfabeta.

Hidayat, F. (2020). Viral Guru Di-bully Murid, Sekolah akan Perkuat Pendidikan Karakter. Detiknews. https://news.detik.com/berita/d-4299012/viral-guru-di-bullymurid-sekolah-akan-perkuat-pendidikan-karakter

Ilyasin, M. (2019). Manajemen Peserta Didik dalam Mengaktualisasikan Nilai-Nilai Karakter di Satuan Pendidikan. Fenomena, 11(1), 69-79. https://doi.org/10.21093/fj.v11i1.2143

Indonesia, K. P. dan K. R. (2017). Konsep dan Pedoman Penguatan Pendidikan Karakter. 64. https://paska.kemdikbud.go.id/wp-content/uploads/2018/07/170222Konsep_dan_Pedoman_PPK-edited.pdf

Kementrian Pendidikan dan Kebudayaan Republik Indonesia. (n.d.). Undang-Undang Sistem Pendidikan Nasional, 2003: UU RI No. 20 tahun 2003 Bab 1 Pasal 1 Nomor 1. Retrieved November 12, 2018, from http://hukum.unsrat.ac.id/uu/uu_20_03.htm

Lichona, T. (2013). Pendidikan Karkter: Panduan lengkap Mendidik Siswa Menjadi Pintar dan Baik Terj. Educating For Character. Nusa Media.

Lubis, D. (2019). Kasus Audrey dan Krisis Pendidikan Karakter Anak. Media Indonesia. https://mediaindonesia.com/opini/229340/kasus-audrey-dan-krisispendidikan-karakter-anak

Majid, A., \& Andayani, D. (2012). Pendidikan Karakter Perspektif Islam. Remaja Rosdakarya. 
Megawangi, R. (2004). Pendidikan Karakter Solusi yang Tepat untuk Membangun Bangsa. BP Migas dan Star Energy.

Misbah, M. (2019). RELASI PATRONASE KIAI-SANTRI DALAM MA ' HADUTHOLABAH BABAKAN TEGAL Patronage Relations of Kyai-Santri in Character Education in Pondok Pendahuluan. Jurnal Smart (Studi Masyarakat, Religi, Dan Tradisi), 05(02), 213-228.

Mu'ayyadah, and Noor Fatmawati. 2021. "Pemanfaatan Teknologi Sebagai Pembelajaran E-Learning Google Classroom Pada Mata Pelajaran IPS.” Asanka: Journal of Social Science and Education 2(1): 31-45. https://jurnal.iainponorogo.ac.id/index.php/asanka/article/view/2364.

Naim, N. (2012). Character Building Optimalisasi Peran Pendidikan Dalam Pengembangan Ilmu dan Pembentukan Karakter Bangsa. Ar-Ruzz.

Nasiki, T. (2017). Implementasi Pendidikan Karakter Di Pondok Pesantren Hubulo. Jurnal Ilmiah Al-Jauhari: Jurnal Studi Islam Dan Interdisipliner, 2(1), 49-65.

Nasir, H. . R. (2005). Mencari Tipologi Format Pendidikan Ideal. Pustaka Pelajar.

Purnomo, D. (2020). Murid Menantang Guru, Bukti Gagalnya Pendidikan Karakter. Kompasiana.

https://www.kompasiana.com/donypurnomo/5c610caebde575270b7c8535/muridmenantang-guru-bukti-gagalnya-pendidikan-karakter

Rohmat, R. (2019). Model Manajemen Pendidikan Karakter Berbasis Integrasi NilaiNilai Religius Dan Multikultural. Jurnal Penelitian Agama, 20(2), 227-266. https://doi.org/10.24090/jpa.v20i2.2019.pp227-266

Saihu, S. (2019). Pendidikan Karakter Berbasis Kearifan Lokal (Studi Di Jembrana Bali). Edukasi Islami: Jurnal Pendidikan Islam, 8(01), 69. https://doi.org/10.30868/ei.v8i01.364

Suardipa, I. P. (2019). PERSPEKTIF LIVING VALUES EDUCATION ( LVE ) DALAM KAJIAN FILSAFAT PENDIDIKAN INDONESIA BERBASIS 3N (NALAR, NURANI, DAN NALURI). MAHA WIDYA BHUWANA, 2(1), 91-99.

Syafe'i, I. (2017). Pondok Pesantren: Lembaga Pendidikan Pembentukan Karakter. Jurnal Pendidikan Islam Publisher: Jurusan Pendidikan Agama Islam Fakultas Tarbiyah Dan Keguruaan Uin Raden Intan Lampung, 8(I), 61-82.

Walid, M. (2011). MODEL PENDIDIKAN KARAKTER DI PERGURUAN TINGGI AGAMA ISLAM ( Studi tentang Pendidikan Karakter Berbasis Ulul albab di Universitas Islam Negeri Maulana Malik Ibrahim Malang ). Jurnal El-Qudwah, 
1(April), 115-156.

Yogyakarta, P. M. B. S. (2020a). Booklet PPM Muhammadiyah Booarding School Yogyakarta.

Yogyakarta, P. M. B. S. (2020b). Buku Agenda PPM Muhammadiyah Booarding School Yogyakarta. 